\title{
Where are the major gaps in the reserve network for Africa's mammals?
}

\author{
Jon Fjeldså, Neil D. Burgess, Simon Blyth and Helen M. de Klerk
}

\begin{abstract}
The establishment of protected areas for wildlife conservation in Africa was motivated by a number of different reasons (including hunting, recreation and wildlife conservation). The current reserve network provides good coverage of the distributions of the 194 species of larger mammals $(>3 \mathrm{~kg}$ ) and 51 species of threatened larger mammals. However, it is less effective in covering the distribution of all 197 of Africa's threatened mammal species, which includes $>140$ smaller bodied species $(<3 \mathrm{~kg})$ often restricted to habitat patches. A fully comprehensive network of areas for the conservation of African mammals, especially those facing extinction, is not yet in place, and further reserves may be needed in the Horn of Africa (Somalia in particular), the Cameroon Highlands, parts of the eastern African coastal forests and Eastern Arc Mountains, and
\end{abstract}

parts of the Albertine Rift Mountains. More and larger reserve areas are also required to adequately cover all the species of South Africa. Parts of these gaps are already covered by government forest reserves, and the importance of this reserve category for the conservation of African mammals, especially threatened species, needs to be better recognized. As many of the gaps in reserve coverage are in areas of high human population and good agricultural potential, conservation goals may be difficult to achieve unless we supplement traditional reserves with novel approaches to maintain natural habitats and wildlife outside reserves.

Keywords Africa, forest reserves, protected areas, reserve network, threatened mammals.

\section{Introduction}

It is already well known that the worlds' protected area network is not optimally located to conserve biodiversity (MacKinnon \& MacKinnon, 1986; Balmford et al., 1992; Pressey \& Tully, 1994; Scott et al., 2001). In Africa, early national parks and wildlife reserves (collectively termed protected areas) were mainly the creation of enthusiasts, often white military sportsmen, whose rationales were variable, and sometimes eccentric (Neumann, 1996). The majority of these protected areas were established in the savannah regions, to protect the megafauna for which the continent is famous and that formed the primary interest of the sport hunters.

Jon Fjeldså (Corresponding author) Zoological Museum, University of Copenhagen, Universitetsparken 15, DK-2100 Copenhagen $\varnothing$, Denmark. E-mail jfjeldsaa@zmuc.ku.dk

Neil D. Burgess WWF-US Conservation Science Programme, 1250 24th Street NW, Washington, DC 20037-1132, USA, and Conservation Biology Group, Zoology Department, University of Cambridge, Downing Street, Cambridge, CB2 3EJ, UK.

Simon Blyth UNEP-World Conservation Monitoring Centre, 219a Huntingdon Road, Cambridge, UK.

Helen M. de Klerk Western Cape Nature Conservation Board - Scientific Services, Private Bag X5014, Stellenbosch, 7599, South Africa.

Received 2 December 2002. Revision requested 4 May 2003. Accepted 8 September 2003.
Declared mainly in the first half of the last century, the location of these protected areas are partly a function of the history of the region. For example, human populations in eastern Africa fell from the early-mid 19th century until the early 20th century, due to a combination of introduced diseases, wars and continued slave trading (Kjekshus, 1977; Sutton, 1990). This resulted in some formerly farmed areas reverting to bush, and allowed increases in wild animals. The associated increase of the tsetse fly and sleeping sickness rendered large areas uninhabitable. Some of these areas, which had supported people only 100 years before, became strongholds for wildlife. As the big animal herds were dwindling in other parts of Africa, many of these wilderness areas, such as the Selous Game Reserve of southern Tanzania, were proclaimed as protected areas. Other reserves were established along national borders, where there was little investment in economic development, and in some cases even a political need for sparsely populated buffer zones (Asiwaju, 1985; Sandwith et al., 2001).

Only a few attempts have been made to identify gaps in the existing network of protected areas in Africa, and hence where additional reserves, or other forms of land use aiming to maintain critical habitats, should be located (Rebelo, 1994; Gelderblom \& Bronner, 1995; Gelderblom et al., 1995; Lombard, 1995; Lombard et al. 1995; Muriuki et al., 1997; de Klerk et al., in press). As the human population of Africa grows and land becomes 
in ever-shorter supply, it is more important than ever to analyse how conservation efforts can become more efficient. A first step is to define whether the existing protected area network adequately conserves the diversity of mammal species in Africa and where the major gaps in protected area coverage are located. This paper looks in particular at how well protected area networks appear to cover the distributions of mammal species threatened with extinction, as preventing extinction is one of the stated aims of international conservation conventions (Ramsar, 1971; UNCED, 1992; WSSD, 2002), and of conservationists (e.g. Pimm et al., 1995). Due to the lack of databases of mammal species for all African protected areas, we have used a probabilistic approach to this analysis.

\section{Methods}

Mammal species distributions come from the 1-degree square resolution databases developed since January 1995 at the Zoological Museum, University of Copenhagen, Denmark (Burgess et al., 1998a; Brooks et al., 2001; Burgess et al., 2002; ZMUC, 2002); we used the August 2003 version of the mammal distribution database. These data follow the most recent publications, including Species Action Plans (IUCN, 2003). For many species the data include the approximate current distributions where these are known (eg. elephant Loxodonta africana, black rhinoceros Diceros bicornis, and various antelope species), although in other cases only historical data or a few known locality records are available (e.g. the insectivore Congosorex polli). The distribution data are digitized in the WORLDMAP software (Williams, 1996), which is also used to perform the analyses presented here.

Four versions of the mammal database were used. The first contains all 946 mammal species in sub-Saharan Africa, excluding species typical of the Palaearctic Realm, those on offshore islands and introduced species. The second contains the 194 mammal species with a body size $>3 \mathrm{~kg}$; this includes all large mammals that have been the focus of attention for developing protected areas, together with the larger species of primates. The third contains the 197 species of African mammals that are categorized as threatened (Critically Endangered, Endangered or Vulnerable) on the IUCN Red List (IUCN, 2002); this list was compiled by the IUCN Species Survival Commission, using guidelines for assessing extinction risks (IUCN, 2001). The fourth version contains only the 51 species of large mammals that are categorized as threatened on the IUCN Red List.

We used version 6.0, August 2003, of the UNEP-World Conservation Monitoring Centre protected area database. Two protected area sub-databases were created. The first included all IUCN category I-VI reserves
(IUCN, 1998) and any national park, game reserve, wildlife management area, faunal reserve, faunal sanctuary, hunting reserve, partial faunal reserve or wildlife reserve that did not have an IUCN reserve code (referred to collectively as wildlife reserves; Fig. 1). The second database included all other terrestrial reserves that had not been coded into IUCN categories. These were denoted as forest reserve, botanical reserve, classified forest, national forest, nature reserve, state forest and state forest reserve 2 , and non-hunting forest reserve (referred to collectively as forest reserves; Fig. 1). The percentage of each onedegree grid cell covered by these reserves was calculated using ArcView 3.2a software (ESRI, 2000). We used the percentages of coverage by protected areas to assess the likelihood that the mammal species occurring in a particular one-degree cell are actually protected. To test the sensitivity of this approach we calculated: (i) the number of mammal species (all mammals, large mammals, all threatened mammals, and threatened large mammals) captured in grid cells with $5,10,25,33$ or $50 \%$ of their area covered by wildlife and wildlife plus forest reserves, and (ii) the minimum number of additional grid-cells required to represent these different groups of mammals (using the principle of complementarity of species distributions; Margules \& Pressey, 2000). The latter analysis, when converted to a percentage of the minimum number of areas required, provides a measure of what additional efforts are needed to supplement the existing protected area network. Because many mammal species occur patchily and at low density, single representations of a particular species may not be enough to secure future population viability; we therefore also examine what is needed to secure up to five representations of all species, where possible.

Two tests were made of the efficiency of sets of grid cells, with various percentages of area protected, at representing the distributions of mammal species. The first was with the same number of cells picked at random from the same database, using a function in WORLDMAP to calculate the median of 1,000 randomly selected sets of areas of each size (Williams 1996; Burgess et al., 2002). The second test calculated, with the idealized near-minimum set, the smallest possible area to represent all threatened species. Near-minimum sets of complementary areas were calculated using a rarity-based heuristic algorithm with redundancy back-checks (Williams et al., 1996). The advantage of this approach, compared with absolute complementarity, is that it allows the flexibility of choice to be assessed.

\section{Results}

The richest areas for all species of mammals in Africa are the montane habitat mosaics of East Africa, the 


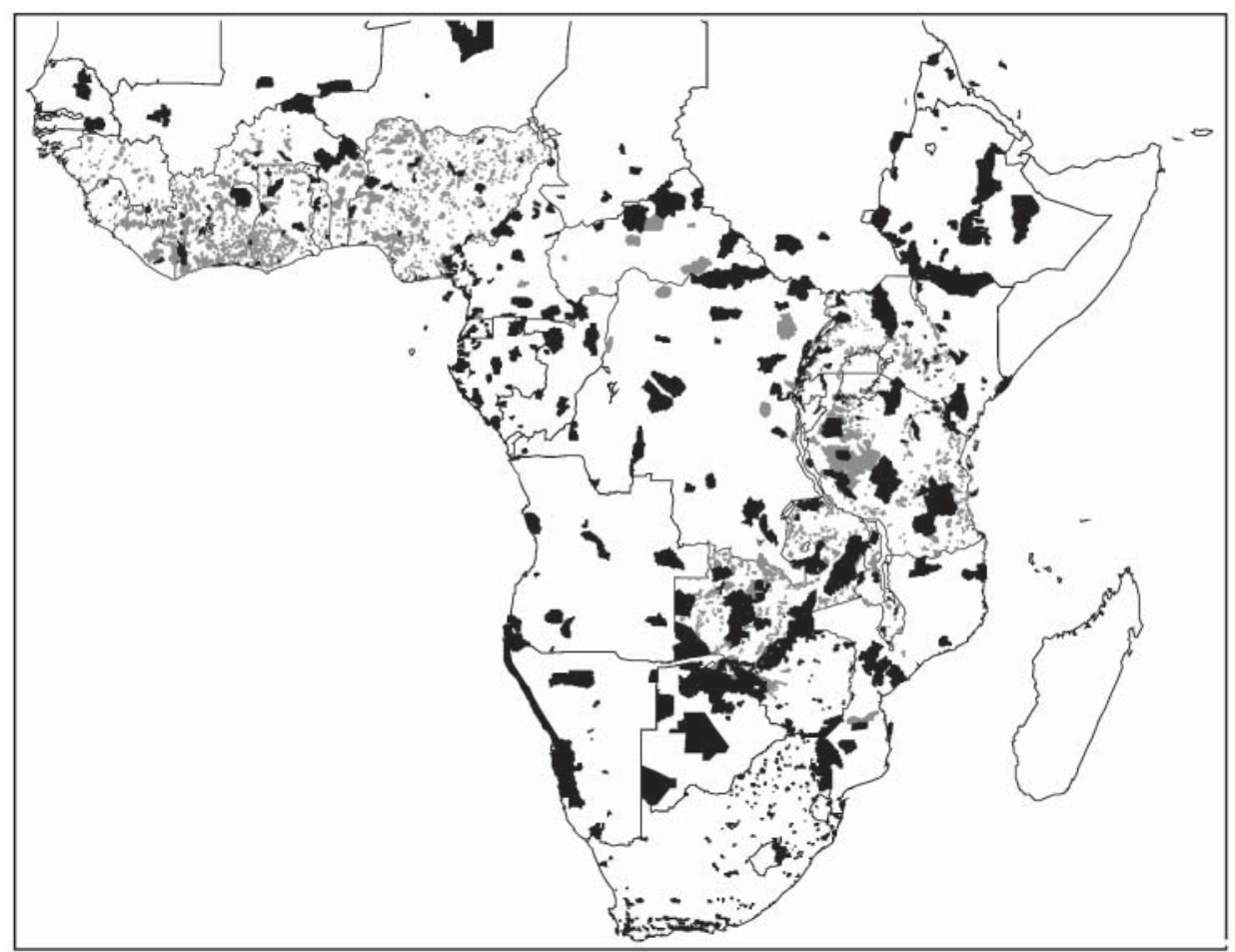

Fig. 1 Distribution of protected areas and other reserves across sub-Saharan Africa, from the August 2003 version of the UNEP-WCMC protected area database: wildlife reserves (black) and forest reserves (grey). See text for definition of wildlife and forest reserves.

woodland savannas of Zambia and Zimbabwe and the transition zones between woodland savannahs and tropical rainforest (Fig. 2a), a pattern that is also followed closely by the large mammal species (Fig. $2 \mathrm{~g}$ ). The number of threatened species is highest in the Sahel zone, in the Upper Guinea forest, at the Horn of Africa, at the Cape and adjacent Namibian savannah zone, in Cameroon-Gabon, and in Africa's montane areas (Fig. 2d). When only the larger threatened mammals are considered, their species richness is concentrated in the Upper Guinea forests of West Africa, the coastal part of the Congo Basin, the Albertine Rift Mountains, Ethiopian Highlands and the Horn of Africa region (Fig. 2j).

\section{Effectiveness of reserve networks}

For the wildlife reserves, between 99 and 514 one-degree grid cells are defined as protected, using our analytical approach, as the percentage protection threshold is varied from 50 to $5 \%$ of a grid cell (Table 1). These protected cells cover different percentages of the four mammal databases, at the same thresholds of protection. Importantly, for every threshold of protection the protected cells cover the largest percentage of large mammals, followed by all mammals, followed by threatened large mammals and finally all threatened mammals. For example, the $5 \%$ threshold of protection covers $96.9 \%$ of the large mammals, $90 \%$ of all mammals, $88.2 \%$ of large threatened mammals and $73.6 \%$ of all threatened mammals (Table 1). The IUCN-coded wildlife reserve network performs worst at covering all threatened mammals.

By adding the network of forest reserves to the wildlife reserves a higher percentage of mammals are covered (Table 1). The species of threatened mammals of West Africa, Kenya, Tanzania and Uganda are better covered than by wildlife reserves alone. This indicates, at this continental scale, the potential consequence to the conservation for African mammals of including well-managed African forest reserves as protected areas under the IUCN coding system.

For species whose total range falls within a single one-degree grid cell, it gives some hope for the long-term survival of the species if a large proportion of this cell is protected. However, this is not the case when more widespread (but rare, patchily distributed and threatened) species are represented in a single 'protected' cell. Multiple representation of a species provides a more realistic evaluation of the needs for additional conservation efforts. As we increase the number of representations of each species, the number of cells in the minimum set rises almost linearly (top line in Table 2). However, the need for additional cells to supplement the existing reserve network shows a stronger proportional increase 
All mammals
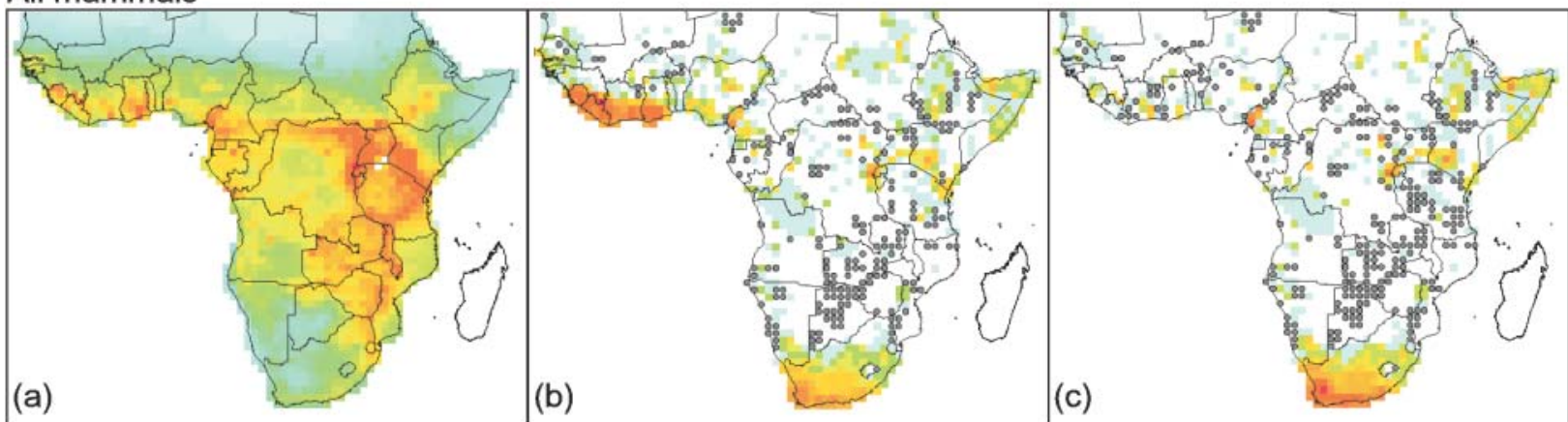

All threatened mammals
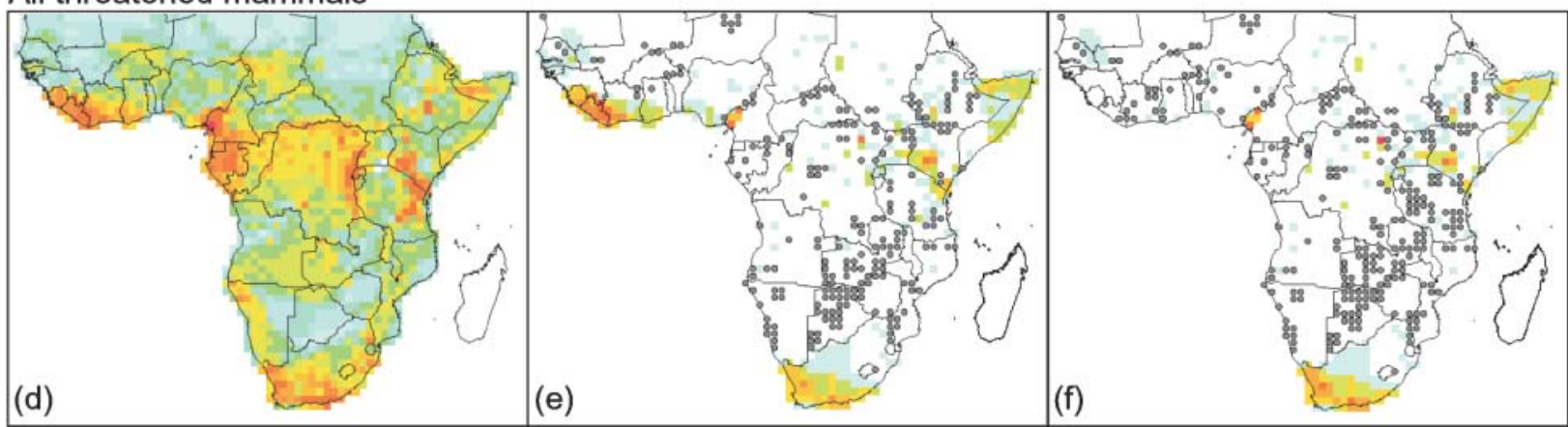

\section{All large mammals}
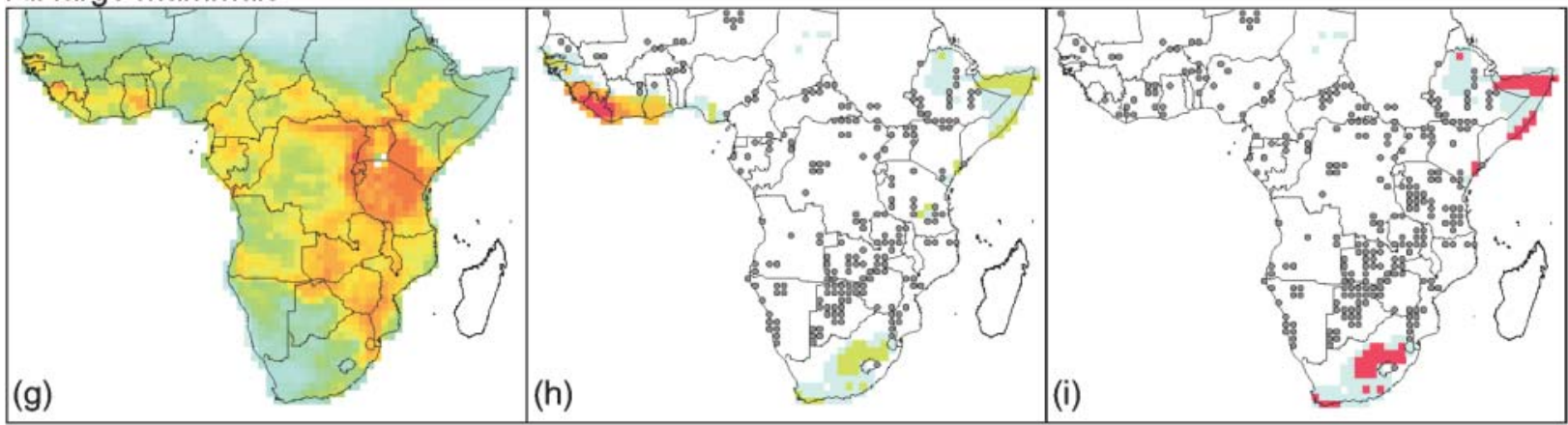

All threatened large mammals

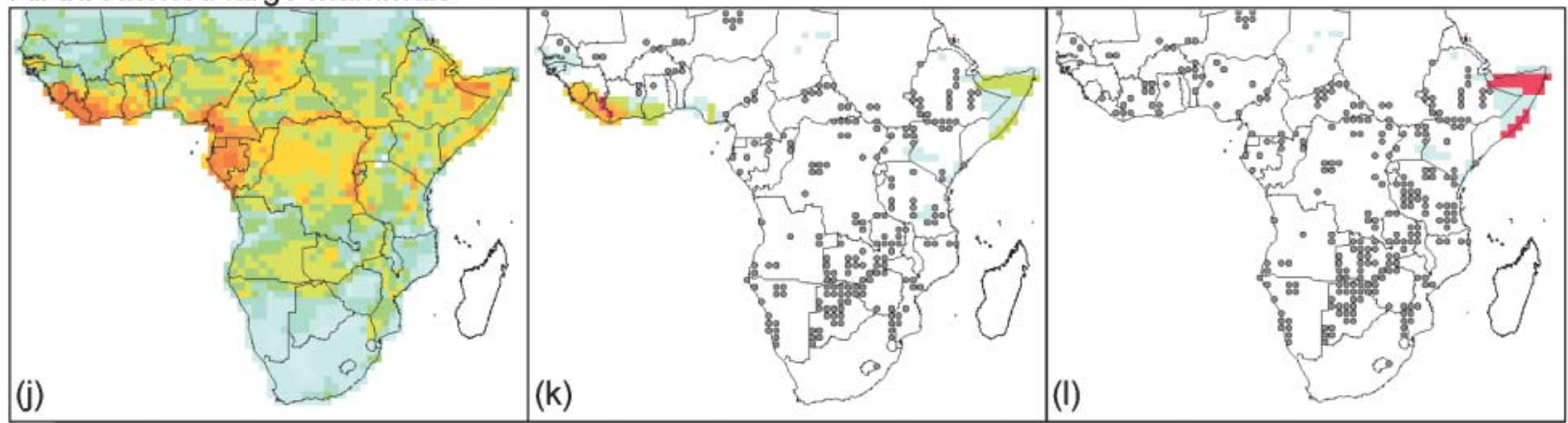

Fig. 2 Geographical patterns in Africa of all 946 species of mammal (top row), all 197 threatened mammal species (second row), all 194 large mammal species (third row), and all 51 threatened large mammal species (bottom row), at a one-degree resolution. The second and third columns illustrate gaps in protection of mammal species when at least $25 \%$ of a grid cell is protected by wildlife reserves and wildlife and forest reserves combined, respectively (grey dots show cells with $<25 \%$ protection). See text for definition of wildlife and forest reserves. 


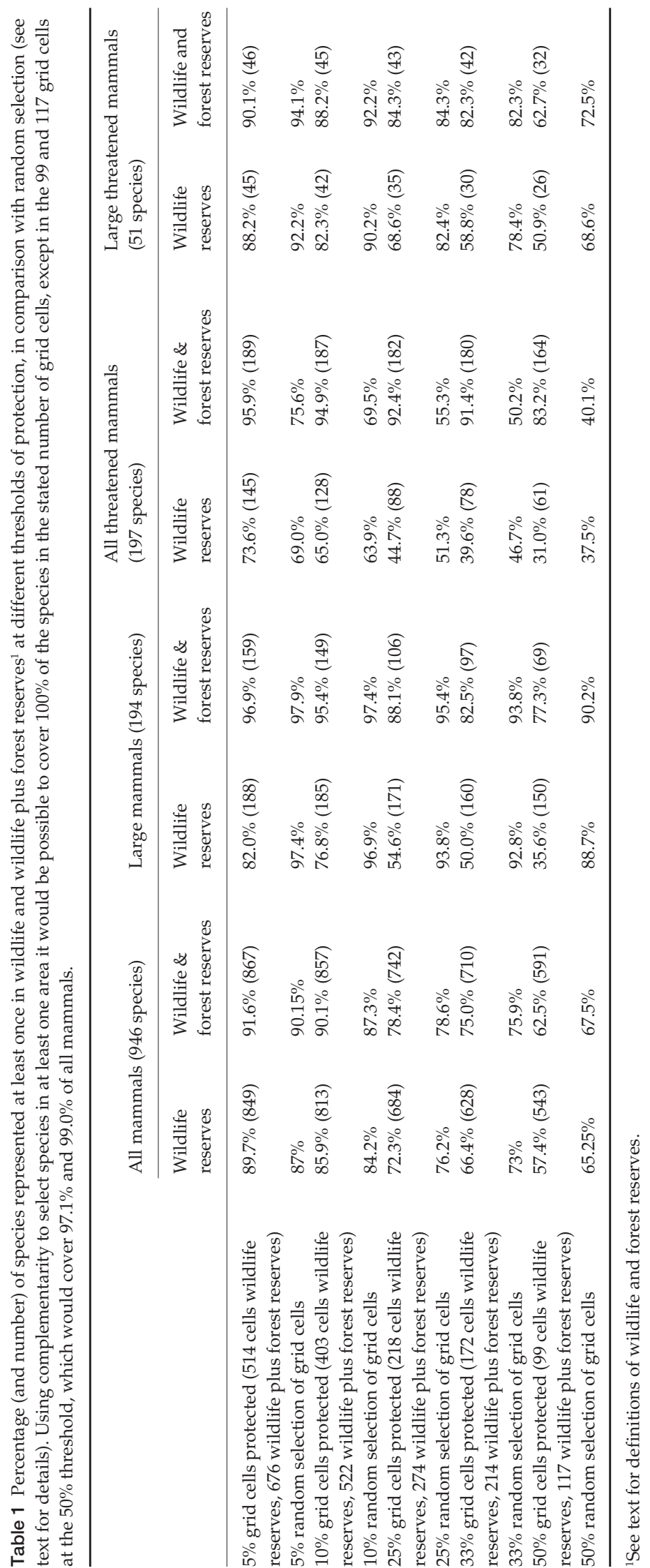


Table 2 Comparison of areas required to represent threatened mammal species 1-5 times, with and without consideration of existing wildlife and forest reserves ${ }^{1}$. See text for details of the calculation of the near-minimum set of one-degree grid cells required to represent all threatened mammal species on the sub-Saharan mainland at least once, twice, three, four and five times. These analyses were repeated considering already protected grid cells that are defined by 5, 10, 25, 33 and 50\% coverage of individual grid cells; the number of additional grid cells required to supplement the already protected grid cells are displayed as percentages of the near-minimum set.

\begin{tabular}{|c|c|c|c|c|c|}
\hline & \multicolumn{5}{|c|}{ No. of times represented } \\
\hline & 1 & 2 & 3 & 4 & 5 \\
\hline \multirow{2}{*}{$\begin{array}{l}\text { No. of grid cells required to represent } \\
\text { threatened species (near-minimum set) }\end{array}$} & 69 & 122 & 156 & 186 & 219 \\
\hline & \multicolumn{5}{|c|}{ Additional areas needed ( $\%$ of near-minimum set) } \\
\hline \multicolumn{6}{|l|}{ Wildlife reserves } \\
\hline 514 grid cells with $>5 \%$ area protected & 50.7 & 54.1 & 53.2 & 53.8 & 56.6 \\
\hline 403 grid cells with $>10 \%$ area protected & 62.3 & 63.9 & 65.4 & 66.1 & 68.0 \\
\hline 218 grid cells with $>25 \%$ area protected & 78.3 & 82.0 & 84.0 & 84.9 & 84.9 \\
\hline 172 grid cells with $>33 \%$ area protected & 82.6 & 86.1 & 87.8 & 89.2 & 88.6 \\
\hline 99 grid cells with $>50 \%$ area protected & 85.5 & 89.3 & 90.4 & 91.4 & 91.8 \\
\hline \multicolumn{6}{|l|}{ Wildlife reserves plus forest reserves } \\
\hline 676 grid cells with $>5 \%$ area protected & 37.7 & 40.2 & 41.0 & 42.5 & 46.1 \\
\hline 522 grid cells with $>10 \%$ area protected & 46.4 & 52.5 & 53.8 & 54.8 & 57.1 \\
\hline 274 grid cells with $>25 \%$ area protected & 72.5 & 77.0 & 79.5 & 80.6 & 80.4 \\
\hline 214 grid cells with $>33 \%$ area protected & 78.3 & 81.1 & 84.0 & 85.5 & 84.5 \\
\hline 117 grid cells with $>50 \%$ area protected & 85.5 & 88.5 & 89.7 & 90.9 & 90.9 \\
\hline
\end{tabular}

${ }^{1}$ See text for definitions of wildlife and forest reserves.

(e.g. from $85.5 \%$ to $91.8 \%$ when using the $>50 \%$ criterion for accepting a cell as protected). This means that, in spite of the substantial area that is already protected, a very substantial amount of supplementary conservation areas are needed.

\section{Gaps in the reserve network}

The distribution of mammals not represented in gridcells protected as wildlife reserves is illustrated in Fig. 2. The major gaps are in the forests of West Africa, the Horn of Africa, parts of South Africa, the Cameroon Highlands, Kenyan Highlands, and parts of the Albertine Rift Mountains, eastern African coastal forests and Eastern Arc Mountains. Most parks and reserves in South Africa are relatively small compared to elsewhere on the continent and hence do not meet the $25 \%$ threshold. When we alter the lowest cut off to $5 \%$, then most of the gaps in species coverage in South Africa disappear, and the coverage of species also rises (Table 1).

For the threatened species, Fig. 2e indicates that there is a small residue of unprotected species; this is because $88(45 \%)$ unprotected species are aggregated in a few areas. The most significant of these are in the forests of West Africa, in the Cameroonian Highlands, South Africa (lowlands of the Cape Fynbos, Succulent Karoo and Succulent Thicket), in Somalia on the African Horn, in the Ethiopia highland, in the Mountains of Kenya, along parts of the Albertine Rift and in the eastern
African coastal forests and Eastern Arc Mountains. The addition of the forest reserves to the network of wildlife reserves reduces the gaps in species coverage significantly (Fig. 2, Table 1). In particular the gaps in protection in the Upper Guinea forests of West Africa are covered well by forest reserves, as are those in the Eastern Arc of Tanzania. However, important gaps remain in the Cameroon Highlands, the Horn of Africa, at higher altitudes in Kenya, and in southern South Africa.

\section{Efficiency of protected area networks}

If we aim at a single representation of each threatened species (Table 1), several of the reserve protection thresholds perform better than random selection. For example, for all mammals the 5 and $10 \%$ thresholds of protection are better than random selection. However, for other thresholds the networks of grid cells regarded as protected are less efficient than random selection of the same number of cells. As there are also many well-placed small wildlife reserves that fall below the 5\% threshold we can assume that the full reserve network is actually better at covering African mammals than is indicated in these tests. The addition of grid cells supporting forest reserves increases the number of mammals protected but lowers the efficiency as the number of grids covered at each threshold of protection is increased markedly (see column 1 of Table 1). 


\section{Discussion}

The wildlife reserve network of Africa covers the distributions of Africa's large mammals relatively well, and in particular those large mammals that are threatened, such as elephant, cheetah Acinonyx jubatus, gorilla (Gorilla spp.), black rhinoceros and bonobo Pan paniscus. The existing reserves are essential for this role alone, and have also helped Africa to maintain its large herds of savannah bovids and other elements of the late Tertiary megafauna that today hardly persist outside this continent. Our results also suggest that the existing network of reserves covers many of the smaller threatened species. For example, the network of reserves defined at the $10 \%$ coverage level is statistically more efficient at covering all threatened mammal distributions than the random selection of grid cells. These results are better than those obtained in a similar study using distribution data for threatened African birds (de Klerk et al., in press), which indicates that the focus on mammals when selecting the location for the African reserves has benefited mammal conservation.

However, there are significant gaps in wildlife reserves for threatened mammals, especially in the forests of West Africa, the Cameroon Highlands, Albertine Rift, Horn of Africa and South Africa. Some of the gaps in South Africa have been noted in studies made at a smaller scale (Gelderblom \& Bronner 1995; Gelderblom et al. 1995). Other forms of government and private reserves also cover some of the gaps in the distribution of protected areas. For example, many African countries contain a network of forest reserves that cover tropical montane and lowland forest (Fig. 1). In some countries, for example Kenya, Uganda, Tanzania and Zimbabwe, these are relatively well protected and provide an important network of protected habitats that are not represented in the protected area network assessed according to IUCN protected area categories. Our results indicate that by including these forest reserves within the network of African protected areas, a larger percentage of mammals will receive some form of protection. The African forest reserves may be particularly important for conserving smaller mammal species, including threatened species. For example, in the Eastern Arc Mountains of Tanzania and Kenya, and the coastal lowland forests of Kenya and Tanzania, most species of threatened forest mammals are confined to forest reserves (Burgess et al., 1998b; Burgess \& Clarke, 2000). However, for larger mammals the forest reserves often afford little protection against hunting, and many of these reserves have been emptied of their larger mammal species to supply the bushmeat trade (Fa et al., 1995; Fitzgibbon et al., 1995; Wilkie \& Carpenter, 1999; Oates, 1999).

Our approach for examining gaps in the protection of African mammals shows some of the broader patterns of gaps and illustrates some issues that require further investigation using finer-scale data. For example, detailed assessments of the species that are actually found in protected areas could be compiled for many parts of Africa (e.g. Kershaw et al., 1994). This would permit a more precise assessment of the current gaps in protected area coverage and hence allow more targeted recommendations to be made. However, reliable mammal species lists are still lacking for a large number of African protected areas.

Although we can demonstrate some of the larger gaps in the protected area network in Africa we also need to consider the feasibility of establishing supplementary reserves. There is a relationship between occurrence of endemic and threatened species and human use of the same areas (Fjeldså et al., 1997, 1999; Balmford et al., 2001). Many parts of Africa with high numbers of threatened mammals (Fig. 1d) have been densely populated for long periods of time (e.g. the Ethiopian highlands, Albertine Rift area, the montane zones of Kenya and Tanzania, around the Bight of Biafra, and the Upper Guinea zone). In the past the specific conditions that allowed threatened species to survive periods of environmental stress may also have meant crop predictability, facilitating the transition from life as hunter-gatherers to resident farming societies, and the development of population centres (Fjeldså et al., 1999). In such areas the reserves also tend to be small and relatively isolated (Harcourt et al., 2001), and in our analyses these areas tend to be those with the most gaps in reserve coverage.

In areas with high human populations, filling conservation gaps will be difficult and expensive (although not unaffordable, see James et al., 1999). Ideally some strictly protected areas should be set aside in every region where conservation gaps occur, as reserved areas provide a secure means to conserve habitats (Oates, 1999; Bruner et al., 2000). However, in addition to efforts to improve the coverage, location and design of protected area networks in Africa, other conservation approaches are also important. Support to more area-intensive production systems may reduce the land degradation resulting from inefficient and extensive landuse (Tiffen et al., 1994). Other off-reserve conservation approaches involve an increased emphasis on ways of revenue sharing and the involvement of local populations in the protection of areas of important habitat. Many such experiments are occurring across Africa in the form of village forest reserves, community-based wildlife reserves, and the implementation of bye-laws recognizing the legal rights of communities to control sacred forests (Hackel, 1999; Hulme and Murphree, 1999; Wily \& Mbaya, 2001). Although these examples provide hope for the future, human population pressure on important biodiversity 
areas is likely to increase (UNDP, 2001). Current economic patterns indicate that most of the next generation of Africans will be subsistence farmers, deriving their fuelwood, meat, medicines and farmland from natural resources, which may require the clearing of large areas of forest and woodland for agricultural production. The development of efficiently located protected areas and mechanisms to maintain natural habitats in farmland areas and the promotion of alternatives to small-scale farming will all be important if the threatened mammals of Africa are to survive into the future, and if more mammals are not to join the Red List (IUCN, 2002) of threatened species.

\section{Acknowledgements}

The many people who have supported the development of our databases are listed elsewhere (Burgess et al., 2002). Louis A. Hansen developed the four versions of the University of Copenhagen mammal database and we think him for his knowledge, skill and commitment. We thank UNEP-WCMC for use of the African protected areas database. Comments and useful discussion were received from Andrew Balmford, Rhys Green and Paul Williams. Paul Williams provided the WORLDMAP software and altered it to our requirements. The databases used in this paper are available for scrutiny upon request to JF.

\section{References}

Asiwaju, A.I. (ed.) (1985) Partitioned Africans: Ethnic Relations Across Africa's International Boundaries, 1884-1984. University of Lagos Press, Lagos, Nigeria.

Balmford, A., Leader-Williams, N. \& Green, M.J.B. (1992) Protected areas of Afrotropical forest: history, status and prospects. In Tropical Rain Forests: An Atlas for Conservation, Vol. 2 (eds M. Collins \& J.A. Sayer), pp. 69-80. MacMillan, London, UK.

Balmford, A., Moore, J.L., Brooks, T., Burgess, N., Hansen, L.A., Williams, P. \& Rahbek, C. (2001) Conservation conflicts across Africa. Science, 291, 2616-2619.

Brooks, T., Balmford, A., Burgess, N., Fjeldså, J., Hansen, L.A., Moore, J., Rahbek, C. \& Williams, P. (2001) Towards a blueprint for conservation in Africa. BioScience, 51, 613-624.

Bruner, A., Gullison, R.E., Rice, R.E. \& Fonseca, G.A.B. (2000) Effectiveness of Parks in protecting tropical biodiversity. Science, 291, 125-128.

Burgess, N., Fjeldså, J., \& Rahbek, C. (1998a) Mapping the distributions of Afrotropical vertebrate groups. Species, 30, 16-17.

Burgess, N.D. \& Clarke, G.P. (2000) The Coastal Forests of Eastern Africa. IUCN Forest Programme, Gland, Switzerland and Cambridge, UK.

Burgess, N.D., Nummelin, M., Fjeldså, J., Howell, K.M., Lukumbyzya, K., Mhando, L., Phillipson, P. \& Vanden Berghe, E. (eds) (1998b) Biodiversity and Conservation of the Eastern Arc Mountains of Tanzania and Kenya. Special Issue of the Journal of the East African Natural History Society, 87, $1-367$.
Burgess, N.D., Rahbek, C., Larsen, F.W., Williams, P. \& Balmford, A. (2002) How much of the vertebrate diversity of sub-Saharan Africa is catered for by recent conservation proposals? Biological Conservation, 107, 327-339.

De Klerk, H.M., Fjeldså, J., Blyth, S. \& Burgess, N.D. (in press) Gaps in the protected area network for threatened Afrotropical birds. Biological Conservation.

ESRI (2000) ArcView 3.2a Software. Environmental Systems Research Institute, Redlands, USA.

Fa, J.E., Just, J., Perez del Val, J. \& Castroviejo, J. (1995) Impact of market hunting on mammal species in Equatorial Guinea. Conservation Biology, 5, 1107-1115.

Fitzgibbon, C.D., Mogaka, H. \& Fanshawe, J.H. (1995) Subsistence hunting in Arabuko-Sokoke forest, Kenya, and its effect on mammal populations. Conservation Biology, 9, 1116-1126.

Fjeldså, J., Ehrlich, D., Lambin, E. \& Prins, E. (1997) Are biodiversity 'hotspots' correlated with current ecoclimatic stability? A pilot study using the NOAA-AVHRR remote sensing data. Biodiversity and Conservation, 6, 401-422.

Fjeldså, J., Lambin, E. \& Mertens, B. (1999) Correlation between endemism and local ecoclimatic stability documented by comparing Andean bird distributions and remotely sensed land surface data. Ecography, 22, 63-78.

Gelderblom, C.M. \& Bronner, G.N. (1995) Patterns of distribution and protection status of the endemic mammals of South Africa. South African Journal of Zoology, 30, 127-135.

Gelderblom, C.M., Bronner, G.N., Lombard, A.T. \& Taylor, P.J. (1995) Patterns of the distribution and current protection status of the Carnivora, Chiroptera and Insectivora in South Africa. South African Journal of Zoology, 30, 103-114.

Hackel, J.D. (1999) Community conservation and the future of Africa's wildlife. Conservation Biology, 13, 726-734.

Harcourt, A.H., Parks, S.A. \& Woodroffe, R. (2001) Human density as an influence on species/area relationships: double jeopardy for small African reserves? Biodiversity and Conservation, 10, 1011-1026.

Hulme, D. \& Murphree, M. (1999) Communities, wildlife and the 'new conservation' in Africa. Journal of International Development, 11, 277-286.

IUCN (1998) 1997 United Nations List of Protected Areas. WCMC/IUCN, Cambridge, UK and Gland, Switzerland.

IUCN (2001) IUCN Red List Categories and Criteria, Version 3.1. IUCN SSC, Gland, Switzerland.

IUCN (2002) 2002 IUCN Red List of Threatened Species. IUCN, Gland, Switzerland and Cambridge, UK [http:/ / www.redlist.org, accessed October 2002].

IUCN (2003) SSC Action Plans. Http://www.iucn.org/themes/ssc/pubs/sscaps.htm [accessed 11 November 2003].

James, A.N., Gaston, K.J. \& Balmford, A. (1999) Balancing the Earth's accounts. Nature, 401, 323-324.

Kershaw, M., Williams, P.H. \& Mace G.M. (1994) Conservation of Afrotropical antelopes: consequences and efficiency of using different site selection methods and diversity criteria. Biodiversity and Conservation, 3, 354-372.

Kjekshus, H.K. (1977) Ecological Control and Development in East Africa. Heinemann Educational Books, Nairobi, Kenya.

Lombard, A.T. (1995) The problems with multi-species conservation: do hotspots, ideal reserves and existing reserves coincide? South African Journal of Zoology, 30, 145-163.

Lombard, A.T., Nicholls, A.O. \& August P.V. (1995) Where should nature reserves be located in South Africa? A snake's perspective. Conservation Biology, 9, 363-372. 
MacKinnon, J. \& MacKinnon, K. (1986) Review of the Protected Area System in the Afrotropical Realm. IUCN, Gland, Switzerland.

Margules, C.R. \& Pressey, R.L. (2000) Systematic conservation planning. Nature, 405, 243-253.

Muriuki, J.N., de Klerk, H.M., Bennun, L.A., Crowe, T.M. \& vanden Berge, E. (1997) Using patterns of distribution and diversity of Kenyan birds to select and prioritize areas for conservation. Biodiversity and Conservation, 6, 191-210.

Neumann, R.P. (1996) Dukes, earls, and ersatz Edens: aristocratic nature preservationists in colonial Africa. Environment and Planning, 14, 79-98.

Oates, J. (1999) Myth and Reality in the Rain Forest: How Conservation Strategies Are Failing in West Africa. California University Press, Berkley, USA.

Pimm, S.L., Russell, G.J., Gittleman, J.L. \& Brooks, T.M. (1995) The future of biodiversity. Science, 269, 347-350.

Pressey, R.L. \& Tully, S.L. (1994) The cost of ad hoc reservation: a case study in western New South Wales. Australian Journal of Ecology, 19, 375-384.

Ramsar (1971) The Ramsar Convention on Wetlands. Ramsar Convention Secretariat, Gland, Switzerland.

Rebelo, A.G. (1994) Iterative selection procedures: centres of endemism and optimal placement of reserves. Strelitzia, 1, 231-257.

Sandwith, T., Shine, C., Hamilton, L. \& Sheppard, D. (2001) Transboundary Protected Areas for Peace and Cooperation. IUCN, Gland, Switzerland and Cambridge, UK.

Scott, J.M., Davis, F.W., McGhie, R.G., Wright, R.G., Groves, C. \& Estes, C. (2001) Nature reserves: do they capture the full range of America's biological diversity? Ecological Applications, 11, 999-1007.

Sutton, J.E.G. (1990) A Thousand Years of East Africa. British Institute in Eastern Africa, Nairobi, Kenya.

Tiffen, M., Mortimore, M. \& Gichuki, F. (1994) More People, Less Erosion. Environmental Recovery in Kenya. John Wiley \& Sons, Chichester, UK.

UNCED (1992) The Rio United Nations Conference on Environment and Development: The Biodiversity Convention, Agenda 21 and the Rio Declaration. UNCED, Gland, Switzerland.

UNDP (2001) World Development Report. UNDP, New York, USA.

Wilkie, D.S. \& Carpenter, J.F. (1999) Bushmeat hunting in the Congo Basin: an assessment of impacts and options for mitigating. Biodiversity and Conservation, 8, 927-955.

Williams, P.H. (1996) WORLDMAP 4.1 WINDOWS: Software and User Document 4.1. Privately distributed, London [http://www.nhm.ac.uk/science/projects/worldmap, accessed 6 November 2003].
Williams, P.H., Prance, G.T., Humphries, C.J. \& Edwards, K.S. (1996) Promise and problems in applying quantitative complementary areas for representing the diversity of some Neotropical plants (families Dichapetalaceae, Lecythidaceae, Caryocaraceae, Chrysobalanaceae and Proteaceae) Biological Journal of the Linnean Society, 58, 125-157.

Wily, L.A. \& Mbaya, S. (2001) Land, People and Forests in Eastern and Southern Africa at the Beginning of the 21st Century: The Impact of Land Relations on the Role of Communities in Forest Future. IUCN Eastern Africa Programme Office, Nairobi, Kenya.

WSSD (2002) Plan of Implementation of the World Summit on Sustainable Development. Http:/ /

www.johannesburgsummit.org [accessed 6 November 2003].

Zoological Museum University of Copenhagen (ZMUC) (2002) Sources Consulted for Compilation of the Mammal Distribution Database for Sub-Saharan Africa. Http:/ / www.zmuc.dk/ commonweb/research/biodata_sources_birds.htm [accessed 11 November 2003].

\section{Biographical sketches}

Jon Fjeldså has undertaken numerous field trips in eastern Africa and has been a member of advisory committees to the Danish government on conservation in Africa. He is also on the international committee of BirdLife Denmark and is the chairman of the Nordic Agency for Development and Ecology, which runs projects in the developing world.

Neil Burgess is a conservation scientist specializing in Africa. Over the past decade he has worked with the University of Copenhagen to assemble data on species distributions across Africa and over the past year has assisted UNEP-WCMC to update their African protected area data for the 2003 World Parks Congress.

Helen de Klerk has worked on the distribution of birds across sub-Saharan Africa and is now involved with the practical implementation of such results in networks of reserves in South Africa, and on training reserve staff in the use of GIS technologies for reserve management.

Simon Blyth has been involved with the protected area databases at the UNEP-World Conservation Monitoring Centre for over 10 years and has overseen the extensive updating that took place for the 2003 World Parks Congress. 